\title{
COVID-19 pandemic impact on the pharmaceutical sector in Bulgaria
}

\author{
Veselina Ivanova ${ }^{1}$, Deyan Pavlov ${ }^{1}$, Tolya Assenova ${ }^{1}$, Emily Terzieva ${ }^{1}$, Petya Milushewa ${ }^{1}$, \\ Alime Djemadan', Gergana Vladimirova ${ }^{1}$, Maria Dimitrova ${ }^{1}$, Maria Kamusheva ${ }^{1}$ \\ 1 Faculty of Pharmacy, Medical University of Sofia, Sofia, Bulgaria \\ Corresponding author: Maria Dimitrova (mia_dimitrova@yahoo.com)
}

Received 15 July 2021 • Accepted 17 July 2021 • Published 15 September 2021

Citation: Ivanova V, Pavlov D, Assenova T, Terzieva E, Milushewa P, Djemadan A, Vladimirova G, Dimitrova M, Kamusheva M (2021) COVID-19 pandemic impact on the pharmaceutical sector in Bulgaria. Pharmacia 68(3): 713-720. https://doi.org/10.3897/ pharmacia.68.e71638

\begin{abstract}
In December, 2019 in Wuhan, Hubei Province, China, a new, unknown strain of coronavirus called SARS-CoV-2 was identified. The virus has spread rapidly to other countries around the world, among which the most affected were Italy, Spain and the United States. As a result, in March 2020 The WHO has declared the new coronavirus epidemic a global pandemic. Despite timely measures and efforts to reduce morbidity, up to date, confirmed cases are 119,452,269, while the number of deaths reached 2,647,662 people. The COVID-19 pandemic has affected all areas of human life - health, social, economic. In each of them, a number of restrictions and obligations were imposed, including wearing of masks, use of disinfectants, education in an online environment, limited work in restaurants and shops. The health sector was particularly affected, and all actors in the pharmaceutical system had to reorganize and adapt their activities in the name of a common goal - ending the COVID-19 pandemic.
\end{abstract}

\section{Keywords}

pandemic, COVID-19, health sector, pharmaceutical system

\section{Introduction}

In March 2020, the WHO declared a global pandemic as a result of the outbreak of COVID-19 in China and its rapid spread around the world. Despite timely measures and efforts to reduce the incidence, to date, confirmed cases are $119,452,269$, while the death toll reaches $2,647,662$ people (WHO 2021).

The pandemic affected all spheres of human life health, social, economic. (Lamber et al. 2020; McKee and Stuckler 2020; WHO 2021) The pharmaceutical industry has been actively involved in the fight against the virus, exploring potential treatment strategies and balancing the supply chain during a crisis. All parties in the pharmaceu- tical sector were forced to focus their resources on overcoming the pandemic (Ayati et al. 2020).

Scientific research focused mainly on the development of drugs and vaccines against viruses and expanding the therapeutic indications of drugs that could have a potential effect on the course of the disease. Globally, 113 drugs and 53 vaccines are in clinical trials (Pontremoli et al. 2020). Legislation and the market authorization also had changes aimed at the application of authorization procedures for the use of early access and the development of mechanisms for early dialogue between the regulator, medical professionals and industry in order to faster and timely collection of efficacy and safety data and to facilitate the assessment of the benefit / risk balance (Cavaleri et al. 2021). 
A number of studies examined possible problems in the production and import of medicines, the risk of shortage of supply of active pharmaceutical ingredients and finished medicinal products, inconsistencies in the supply chain. Wholesale and retail trade, as well as medical services were affected, and the need to strengthen the role of pharmacists has been felt (Badreldin and Atallah 2021; Pinto et al. 2021).

Due to the imposed anti-epidemic measures, it has become common practice for physicians to consult remotely patients, especially those with chronic diseases, and with pharmacists when dispensing prescribed drugs, thus enhancing the application of telecommunications in healthcare. (Galiero et al. 2020; Lieneck et al. 2020) Patients' use of chronic medicines, personal protective equipment, medical devices and respiratory medicines has increased (Cohen and van der Meulen Rodgers 2020).

The purpose of this review was to make a critical analysis of studies published in the literature assessing the impact of the COVID-19 pandemic on various activities in the pharmaceutical sector, as well as an assessment of changes in the Bulgarian health and pharmaceutical legislation related to the pandemic.

\section{Methods}

A literature review was conducted on the keywords "pandemic", "COVID-19", "pharmaceuticalsector" in the scientific databases of PubMed, Scopus, GoogleScholar publications assess the impact of the COVID-19 pandemic on activities in the pharmaceutical sector and critical analysis of challenges and changes, facing the participants in the pharmaceutical system.

A legislative analysis of the updates on health and pharmaceutical legislation in 2020 has been made in response to the changes that have occurred as a result of the global pandemic of COVID-19 in the pharmaceutical sector in Bulgaria.

A pilot, online, anonymous, survey was conducted among employees of pharmaceutical companies in Bulgaria to assess the impact of COVID-19 pandemic on their work and to identify opportunities for the pharmaceutical industry to cope with the effects of the pandemic. For this purpose, a special questionnaire was created, which was sent to employees of various innovative and generic pharmaceutical companies in the period 01.05.2021-31.05.2021. Descriptive statistics were applied in Microsoft Excel to process the results.

\section{Results}

\section{Literature review}

As a result of the literature search, a total of 31 studies were found ( 4 for clinical trials and development of drugs, 2 for legislation and marketing authorization, 6 in the field of drug supply process, 2 for wholesale and retail trade, 5 in the field of medical care, 9 in the field of pharmaceutical care, 3 for use by patients). The literature review showed that the COVID-19 pandemic had an impact in all areas of the pharmaceutical sector.

\section{Critical analysis}

Table 1. Areas in the pharmaceutical sector affected my the COVID-19 pandemic.

\begin{tabular}{|c|c|c|}
\hline Area & Changes & Measures \\
\hline $\begin{array}{l}\text { Research and } \\
\text { development } \\
\text { and clinical } \\
\text { trials }\end{array}$ & $\begin{array}{l}\text { - Termination or postpone of } \\
\text { a large part of the clinical } \\
\text { trials for various indications } \\
\text { - Launch of many clinical } \\
\text { trials for treatment and } \\
\text { vaccine against COVID-19 }\end{array}$ & $\begin{array}{l}\text { - Introduction of new } \\
\text { guidelines for conducting } \\
\text { clinical trials by EMA and } \\
\text { FDA }\end{array}$ \\
\hline $\begin{array}{l}\text { Marketing } \\
\text { authorization } \\
\text { and quality } \\
\text { control }\end{array}$ & $\begin{array}{l}\text { - Increased Application of } \\
\text { conditional marketing } \\
\text { authorization COVID-19 } \\
\text { medicines } \\
\text { - Reorganization of the } \\
\text { therapeutic application of } \\
\text { medicines without a patent }\end{array}$ & $\begin{array}{l}\text { - Conduct clinical trials to } \\
\text { evaluate the efficacy of } \\
\text { a number of medicinal } \\
\text { products }\end{array}$ \\
\hline $\begin{array}{l}\text { Manufacturing } \\
\text { of medicinal } \\
\text { products }\end{array}$ & $\begin{array}{l}\text { - Failure in the global supply } \\
\text { chain; } \\
\text { - Lack of active substances } \\
\text { - Lack of basic and life-saving } \\
\text { drugs }\end{array}$ & $\begin{array}{l}\text { - Focus on creating an } \\
\text { efficient supply chain } \\
\text { - Positive opportunities for } \\
\text { risk management }\end{array}$ \\
\hline $\begin{array}{l}\text { Wholesale and } \\
\text { retail trade }\end{array}$ & $\begin{array}{l}\text { - Increased risk of lack } \\
\text { of basic medicines and } \\
\text { personal protective } \\
\text { equipment }\end{array}$ & $\begin{array}{l}\text { - Imposed restrictions on } \\
\text { the quantity of medicines } \\
\text { purchased } \\
\text { - Delivery of medicinal } \\
\text { products to homes }\end{array}$ \\
\hline Medical care & $\begin{array}{l}\text { - Providing medical care from } \\
\text { a distance }\end{array}$ & $\begin{array}{l}\text { - Rise of telemedicine } \\
\text { - Introduction of a } \\
\text { telemedicine device for } \\
\text { collecting patients health } \\
\text { data }\end{array}$ \\
\hline \multirow[t]{3}{*}{$\begin{array}{l}\text { Pharmaceutical } \\
\text { care }\end{array}$} & \multirow{3}{*}{$\begin{array}{l}\text { - Strengthening the role of the } \\
\text { pharmacist in maintaining } \\
\text { the health of patients } \\
\text { - Introduction of new } \\
\text { pharmaceutical services } \\
\text { - Challenges for industrial } \\
\text { pharmacists }\end{array}$} & $\begin{array}{l}\text { - Providing reliable } \\
\text { information and advice to } \\
\text { patients }\end{array}$ \\
\hline & & $\begin{array}{l}\text { - Ensuring uninterrupted } \\
\text { access to medicines }\end{array}$ \\
\hline & & $\begin{array}{l}\text { - Ensuring safe and } \\
\text { appropriate use of medicnes } \\
\text { during clinical trials }\end{array}$ \\
\hline Drug utilization & $\begin{array}{l}\text { - Deterioration of access to } \\
\text { medicnes } \\
\text { - Mental damage }\end{array}$ & $\begin{array}{l}\text { - Care and support from } \\
\text { pharmacists }\end{array}$ \\
\hline
\end{tabular}

\section{Critical analysis of the changes in the Bulgarian pharmaceutical legislation during the pandemic}

The conducted legislative analysis examines the updates made to the health and pharmaceutical legislation in 2020 in response to the COVID-19 pandemic in Bulgaria. The results show that the basic health laws have undergone a number of changes in 2020, which are described in Table 2.

The amendments to the Health Act, the Medical Establishments Act and the Health Insurance Act aim to determine the measures on the territory of the Republic of Bulgaria to prevent, limit and overcome the consequences of the spread and infection with the COVID-19. The aim 
Table 2. Update in the health and pharmaceutical Bulgarian legislation during the COVID-19 pandemic.

\begin{tabular}{|c|c|c|}
\hline $\begin{array}{c}\text { Legislative } \\
\text { document }\end{array}$ & Change & Reason for update \\
\hline \multicolumn{3}{|c|}{ Health legislation } \\
\hline $\begin{array}{l}\text { Bulgarian } \\
\text { Health Law }\end{array}$ & $\begin{array}{l}\text { In case of an emergency epidemic or a threat to the health of citizens from diseases other than those } \\
\text { listed, the Minister of Health may order mandatory isolation of patients and infectious agents and } \\
\text { quarantine of contact persons and persons who have entered the country from other countries. } \\
\text { The obligatory isolation of patients or contact persons can be carried out at home at the discretion of the } \\
\text { attending physician. } \\
\text { In case of introduced anti-epidemic measures, the contact persons of the patients with infectious diseases } \\
\text { cannot refuse to perform an examination in order to establish the carrier of a contagious disease. } \\
\text { Whoever violates or fails to implement the introduced anti-epidemic measures, unless the act constitutes } \\
\text { a crime, shall be punished by a fine in the amount of BGN 5,000. BGN } \\
\text { The law regulates the possibility of switching to teleworking or home-office mode in a complicated } \\
\text { epidemiological situation. } \\
\text { The Minister of Health may pay additional remuneration for the results achieved by employees in the } \\
\text { system of the Ministry of Health, working in unfavorable working conditions during the declaration of } \\
\text { a state of emergency, respectively of an emergency epidemic situation, including for activities related to } \\
\text { vaccination against COVID-19. }\end{array}$ & $\begin{array}{l}\text { Restricting the spread of COVID-19. } \\
\text { Compliance with anti-epidemiological } \\
\text { measures. Reducing the pressure on } \\
\text { medical institutions. Ensuring safety } \\
\text { and encouraging workers in unfavorable } \\
\text { working conditions during the declaration } \\
\text { of a state of emergency. }\end{array}$ \\
\hline $\begin{array}{l}\text { Bulgarian law } \\
\text { on medical } \\
\text { establishements }\end{array}$ & $\begin{array}{l}\text { The changes in the law provide opportunities for restructuring of hospital wards and hospitals for the } \\
\text { treatment of patients with COVID-19. } \\
\text { Pursuant to the Law on Medical Establishments, the Ministry of Health may subsidize medical } \\
\text { establishments for hospital care to maintain their readiness to provide medical care in the event of an } \\
\text { emergency situation. } \\
\text { As a result of the changes in the law, vaccination centers are being opened. } \\
\text { The law enabled the establishment of programs for recovery and rehabilitation of people suffering from } \\
\text { COVID-19. }\end{array}$ & $\begin{array}{l}\text { Providing quality medical care and the } \\
\text { necessary bedding. Providing funds as } \\
\text { needed to combat COVID-19. Faster } \\
\text { access to group immunity. Dealing with } \\
\text { "post-Covid syndrome". }\end{array}$ \\
\hline $\begin{array}{l}\text { Bulgarian } \\
\text { law on health } \\
\text { insurance }\end{array}$ & $\begin{array}{l}\text { Funds are provided for the purchase of protective equipment and medical equipment for the treatment of } \\
\text { patients with COVID-19. } \\
\text { General practitioners may issue electronic referrals for PCR testing; } \\
\text { Funds are provided for the purchase of medicines needed to combat COVID-19. } \\
\text { Gradually, the introduction of electronic prescriptions begins. } \\
\text { Pharmacies may dispense medicinal products only with a prescription book, without presenting a } \\
\text { prescription according to the last entered in the prescription book data for dispensed medicinal products, } \\
\text { under conditions and in accordance with the procedure established by the National Health Insurance } \\
\text { Fund, until the state of emergency is revoked and two months after its revocation. }\end{array}$ & $\begin{array}{l}\text { Ensuring the necessary safety of workers } \\
\text { in adverse working conditions and the } \\
\text { treatment of patients with COVID-19. } \\
\text { Study and control of the spread of } \\
\text { COVID-19. Providing the necessary } \\
\text { treatment. Improving the control of } \\
\text { prescribing and dispensing of drugs and } \\
\text { reducing the risk of errors in prescribing } \\
\text { drugs. Restricting the spread of COVID-19 }\end{array}$ \\
\hline \multicolumn{3}{|c|}{ Pharmaceutical legislation } \\
\hline $\begin{array}{l}\text { Bulgarian law } \\
\text { on medicinal } \\
\text { products } \\
\text { in human } \\
\text { medicine }\end{array}$ & $\begin{array}{l}\text { Change in the terms for parallel import in emergency situations and epidemic conditions; } \\
\text { Prohibition of export of drugs from the Bulgarian Drug Agency (BDA) in emergency situations; } \\
\text { Through the Transparency Commission it is possible to allow the application of medicines, which has a } \\
\text { marketing authorization (MA) in the EU, MA in Bulgaria, but is not distributed on the Bulgarian market } \\
\text { in case of lack of alternative treatment for specific patients; } \\
\text { Common EU logo of online pharmacies; } \\
\text { The introduction of a system for verification of medicinal products throughout Europe. }\end{array}$ & \begin{tabular}{|} 
Faster drug supply process during a \\
pandemic. Providing Bulgarian patients \\
with basic groups of drugs for the \\
treatment of COVID-19. Adequate \\
treatment and medical care for patients. \\
Protecting consumers from unfair traders \\
in a pandemic. Delivery of authentic and \\
safe medicinal products.
\end{tabular} \\
\hline
\end{tabular}

is to regulate measures in the field of health care, through which to reduce and slow down the spread of the epidemic. Providing an opportunity to prepare the health system to meet the challenges and ensure adequate medical care for individuals.

The main changes in the pharmaceutical legislation are aimed at achieving a faster response to the COVID-19 crisis in terms of regulation of production, conducting clinical trials and providing faster access to treatment with medicines developed for COVID-19.

\section{Questionnaire survey}

The survey was sent electronically to employees of pharmaceutical companies represented in Bulgaria. The predominant number of respondents work at innovative companies $87 \%(n=26)$. The transition to home-office and the uncertain economic environment are the most likely factors influencing the reduction of hiring new employees, as well as the tendency to hybridize roles and responsibilities and restructure the duties and functions of employees not only locally but also globally. The pandemic initiates the digitalization, requires transition to remote work and use of more technologies to solve daily tasks. Prohibited and restricted travel, conferences and access to the offices require regular holding of virtual meetings, which is accompanied by an additional workload for the employees. The work of medical representatives and their meetings with physicians has been seriously hindered, which is partially offset by introduction of digital communication platforms and digital channels for promotion. Home office and social distance during COVID-19 pandemic require introduction of innovative practices such as virtual groups for "drinking coffee" or "competitions" that increase the mood and physical activity of employees (Fig. 1).

Respondents cited new recruitment, sales of certain medicines (eg common products), marketing activities, as well as research potential (R\&D) and innovation investment planning (Fig. 2) as the main sectors affected by the pandemic. The IT sectors and sales of certain products used for treatment of COVID-19 symptoms were the most positively influenced (Fig. 3). 


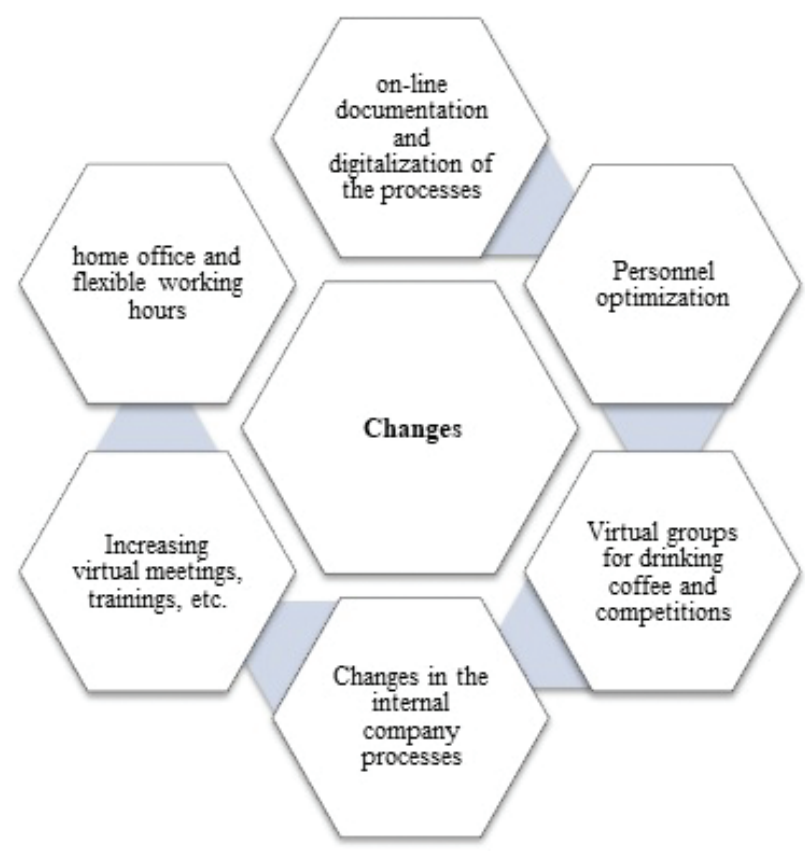

Figure 1. Work flow changes in pharmaceutical companies due to COVID-19.
All respondents point out the acceleration of digitalization in the sector as the main and most significant positive consequence, as well as the optimization of work process and employees' activities. Communication with medical professionals is defined as very difficult, which predetermines the introduction of new methods of information exchange, new marketing strategies and digital advertising. Problems are reported with the production, import and sale of certain medicinal products, as well as in financing of innovative activities due to the financial constraints. There is a deterioration in the access of chronically ill patients to health care, delayed diagnosis, negative impact on timely diagnosis and early staging of severe and socially significant diseases, which affects negatively the pharmaceutical companies and leads to decline in sales (Fig. 4).

\section{Discussion}

The spread of the new coronavirus, which causes COVID-19, has led to a severe public health emergency nationally and globally. The health systems of all countries

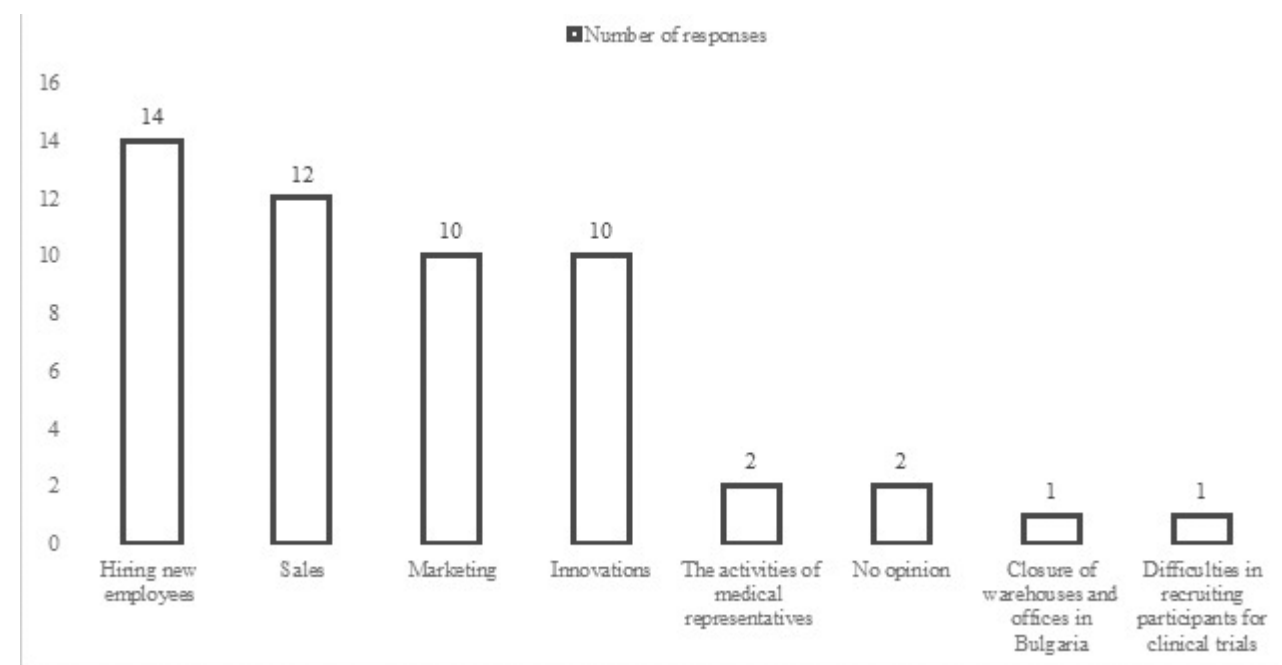

Figure 2. Sectors negatively affected by COVID-19.

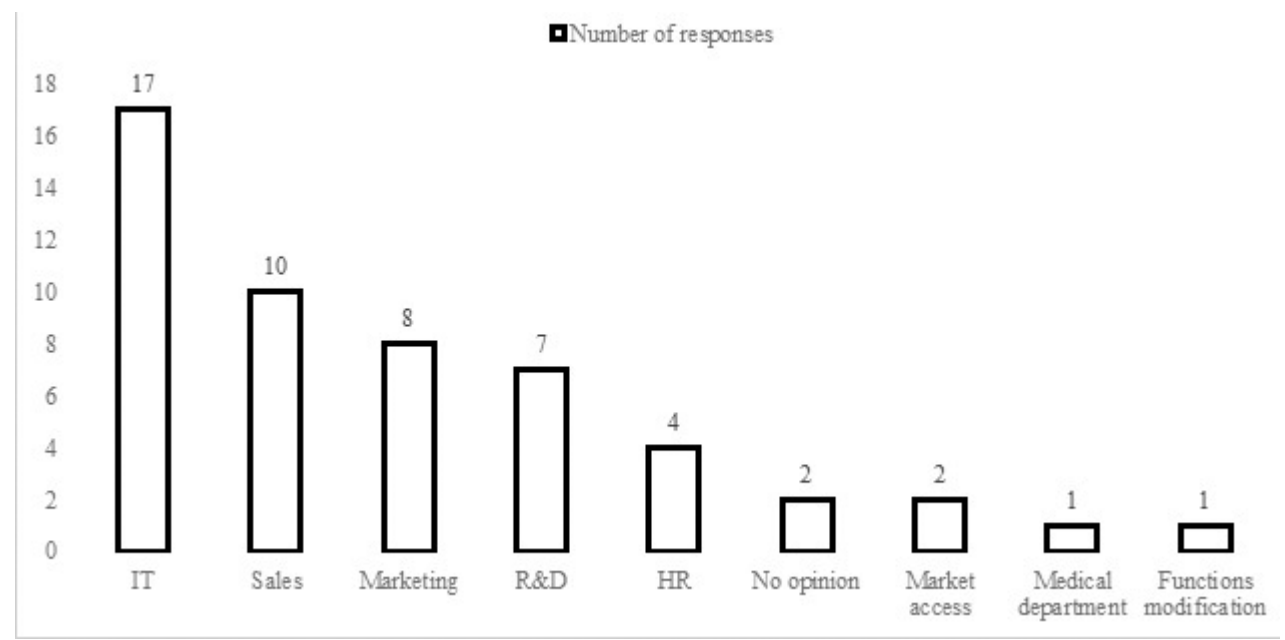

Figure 3. Sectors positively affected by COVID-19. 


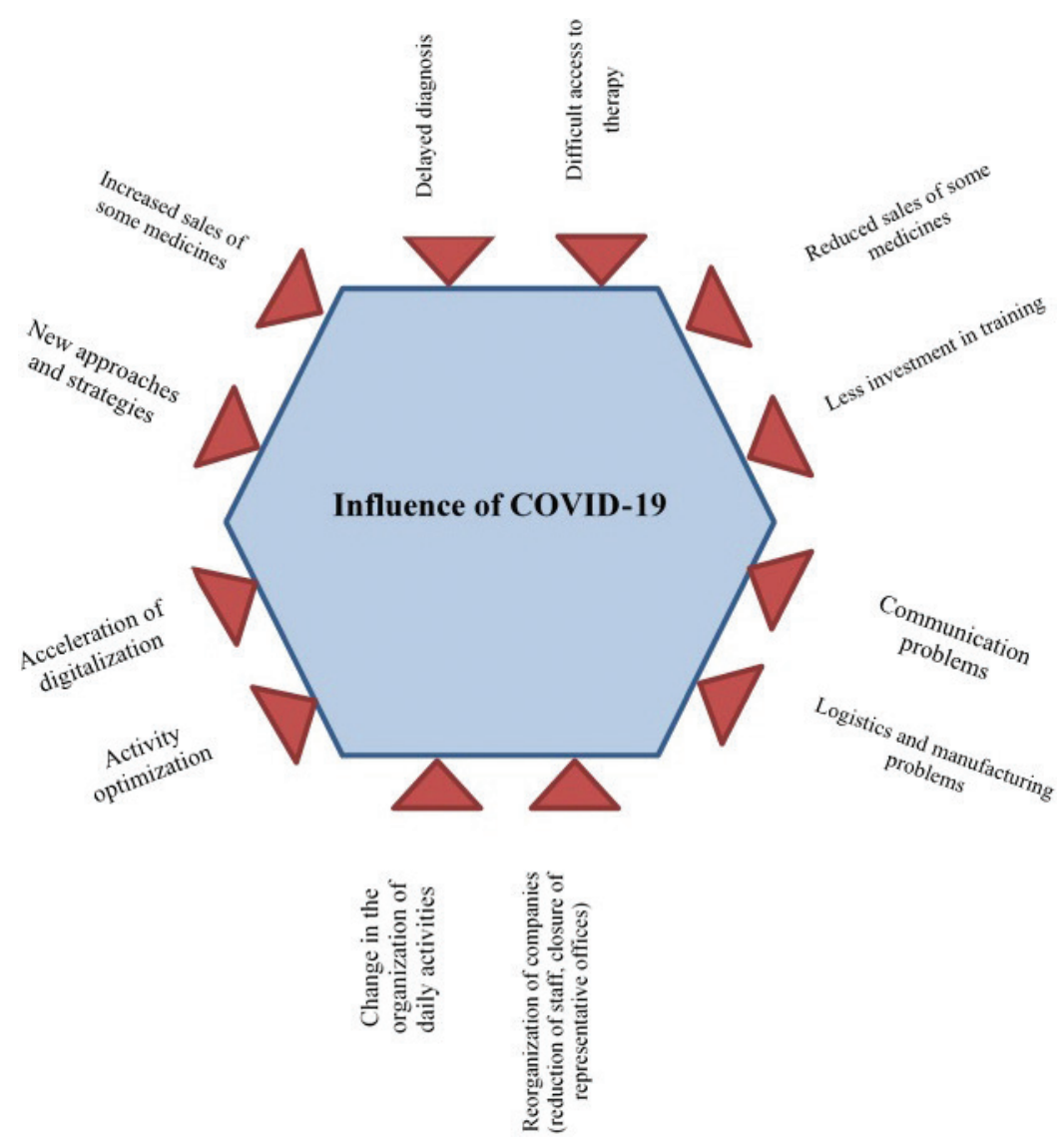

Figure 4. Influence of COVID-19 on the pharmaceutical industry in Bulgaria.

faced a huge challenge related to preventing, limiting and overcoming the consequences of the spread of COVID-19, providing timely medical care, adequate drug therapy and limiting the risk of shortage of essential medicines.

Medicines manufacturing was hampered by restrictions on the work of companies, infected staff, low availability of raw materials and therefore the transportation of the product across borders (West et al. 2020). On the other hand, there has been a trend towards mass information on as yet unproven treatments which has led to a stockpile of medicines needed for critically ill patients, in particular sedatives and opioids (Shuman et al. 2020). The sudden increase in the number of seriously ill patients has led to the need for much larger amounts of medicines. The above consequences of the pandemic caused a shortage of essential (and life-saving) drugs, as well as those needed to treat critically ill patients. The main factor was the increased demand, as the effect on the supply and access to medicines was tangible (Golan et al. 2020).

Covid-19 did not fail to affect the wholesale and retail trade in medicines as well. Too many factors have led to an increased risk of shortages of a number of drugs in warehouses, respectively in pharmacies and hospitals. The main factors determining this risk were the larger volume of orders for the purpose of stockpiling pharmacies, difficulties in the supply chain of medicines in terms of supply, restrictions in the production process, panicked purchases of medicines and personal protective equipment from cit- izens (Boškoski et al. 2020; Romano et al. 2021). In many countries, authorities have been forced to take some urgent actions. For example, the legislation imposed restrictions on the quantities of medicines that can be purchased by citizens. Also, in accordance with the latest EU guidelines, pharmacies were allowed to deliver medicines to their homes.

In the midst of the pandemic, it was important to ensure that patients maintained safe and timely access to their medications in order to avoid disease progression or worsening of symptoms due to potential delays or interruptions in treatment. The pandemic has forced the health care system of many countries to undergo transformations, with telemedicine being one of the main drivers of change.

Telemedicine enables physicians to provide remote medical care, such as reviewing patients' drug histories, managing therapy. It promotes the measure of social distancing by minimizing personal visits and reducing personal contact between doctors and patients. Physicians can use telemedicine-approved video and audio communication applications to limit the spread of coronavirus (Haque 2021). Among the novelties is the use of a mobile telemedicine device for efficient collection, transformation and evaluation of patients' health data to be transmitted to the attending physician. Telemedicine technology is widely available, inexpensive and widely accepted by doctors and patients. However, it faces a number of challenges (Antony Jr 2020). The competence of patients regarding the use of mobile equipment must be in- 
creased, as well as the confidentiality of their data. The patient and the doctor need quality equipment to ensure a quality connection. Another problem may be the difficult access to the Internet and the insufficient resources of some hospitals to manage the increase in virtual patient care (Caetano et al. 2020). Healthcare professionals differ on the use of telehealth for patient care. Some see it as a huge step in healthcare, while others are more skeptical about its applicability in this area. Telemedicine is expected to have a significant effect on improving healthcare in the future (Doraiswamy et al. 2020). It is being used with tremendous speed and scale, becoming part of the "front line" of the battle against the pandemic (Mann et al. 2020).

Among the novelties is telepharmacy (a practical aspect of telemedicine, which refers to the provision of pharmaceutical services from a distance). This service will be useful not only for patients with COVID-19, but also for chronically ill patients and those with limited mobility in the background of quarantine. An indispensable part of the "first line" are pharmacists, better known as the most affordable medical professionals. Their role in times of crisis, such as the current pandemic, is crucial, as they are the first and last point of contact with patients (Visacri et al. 2021). Pharmacists are involved at various levels in disease control and prevention, patient care and treatment during the COVID-19 pandemic (Amariles et al. 2021).

In addition to standard pharmaceutical care and responsibilities, the pandemic has posed a number of challenges to pharmacists, increasing their importance in ensuring patient health (Goncalo et al. 2021; Ballard et al. 2020). Pharmacies have expanded their role in providing the best possible care during the COVID-19 pandemic by receiving legislative support. The actions taken by pharmacists play a vital role in increasing the efficiency of congested health systems. Among the new powers of pharmacists are the introduction of social distance methods in pharmacies, despite the increasing number of patients, to limit the spread of the virus. Patients were instructed on how to protect themselves from infection and explained the proper use of protective masks.

In the face of the pandemic, new pharmaceutical services were introduced, and the process is related to the concept of e-health. In some countries, pharmacists have been given the right to prescribe medicines for themselves and their next of kin, as well as for emergency patients to take an active part in vaccination programs (FIP 2020). They guide people about the disease, its causes and routes of transmission, thus helping to neutralize confusion in the general community and prevent self-medication.

The COVID-19 pandemic is accompanied by rapidly spreading myths about treatment and prevention. Pharmacists have a key role to play in dispelling these myths by providing reliable information to the public (Hussain et al. 2020). The pharmacist has a role to play in ensuring that patients have continued access to medicines, despite deteriorating supply chains and shortages of medicines. He must strive to procure and store the right amount of medicines to ensure timely delivery (Merks et al. 2021).
To ensure an adequate supply of medicines, especially in small towns, pharmacists can arrange home deliveries.

In the absence of specific treatment for COVID-19, society is in dire need of clinical guidelines and a treatment algorithm. Pharmacists, physiciand and other health professionals can work together to develop these guidelines. In addition to the physical health of patients, pharmacists also provide psychological support to those in need. They need to pay attention to their emotional state and identify patients with excessive anxiety or fear.

The main challenges for the pharmaceutical industry in the conditions of lockdown are related to logistical difficulties and delays in deliveries (McCabe 2020). Our study shows that the impact of COVID-19 on the pharmaceutical industry in Bulgaria, determined by the employees of the companies, can be considered in two main aspects: positive and negative consequences. In the course of the COVID-19 pandemic, the pharmaceutical companies members of EFPIA (European Federation of Pharmaceutical Industries and Associations) are working hard to develop vaccines, methods for diagnosing and treating of COVID-19, and to provide conditions for patients' adequate access to medicines. More than 100 candidate vaccines are being developed worldwide and more than 600 clinical trials are being conducted to find a cure for COVID-19 (EFPIA 2020). Along with the intensified work bringing significant benefits for the society in pandemic conditions, pharmaceutical companies face a number of difficulties and challenges. The pandemic has helped accelerate the digital transformation of the pharmaceutical industry, which is critical to improve patient care, cost-effectiveness, greater transparency, and improved drug manufacturing and development processes.

A survey shows that COVID-19 accelerates the digitalisation of the sector, as $30 \%$ of respondents believe that this process has been accelerated by the pandemic with more than 6 years (Pharmaceutical Technology 2021).

Our study confirms that Bulgarian employees in the pharmaceutical companies also assess the positive impact of the pandemic on the digitalization and optimization of activities. Other major positive effects are the growing demand of medicines for prevention and treatment of coronavirus and the focus on vaccine development. COVID-19 enables companies to demonstrate the importance of their investment in vaccines and medicines and to demonstrate the positive and essential role they play in society. COVID-19 stressed the importance of building the sustainability in the drug supply chain and independence from China (the largest producer of active substances).

On the other hand, there is a negative consequence: decrease in sales of medicines for chronic diseases and limited funding for innovation (PWC 2020). Our respondents' opinion on the pandemic impact on the sector is confirmed by the data of The Irish Times on the negative effects of the pandemic on the pharmaceutical industry. According to the study, Pfizer reported a decrease in sales for the third quarter by $\$ 500$ million, or $4 \%$, due to the effects of the virus. In Eli Lilly, key diabetes therapies reduce 
revenue as job loss pushes people to buy cheaper medicines. Merck Sharp \& Dohme reported \$ 475 million in losses from the pandemic globally due to reduced sales of therapies not for treatement of COVID-19, such as Gardasil for HPV (Ayati et al. 2020). Bulgarian pharmaceutical and cosmetic companies have also been financially affected by the pandemic. The data for 2020, compared to 2019 of three Bulgarian companies show changes in their shares - Tchaikapharma VL (+ $20 \%$ return on shares), Lavena and Sopharma (-6\% return on shares, respectively) (Todorov 2020).

The companies working in the development of vaccines and therapies aimed at COVID-19 have a positive impact. Thus, companies such as Moderna, Novavax and BioNTech report huge revenue growth for the third quarter of 2019 compared to 2020 (Google Finances Moderna 2021; Google Finances Novavax 2021; Google Finances BioNTech 2021). Despite large investments in vaccine develop-

\section{References}

Amariles P, Ledezma-Morales M, Salazar-Ospina A, Hincapié-García JA (2021) Pharmacist's Role and Pharmaceutical Care During the COVID-19 Pandemic. In: Rezaei N (Ed.) Coronavirus Disease - COVID-19. Advances in Experimental Medicine and Biology, vol. 1318 Springer, Cham. https://doi.org/10.1007/978-3-030-63761-3_33

Anthony Jr B (2020) Use of telemedicine and virtual care for remote treatment in response to COVID-19 pandemic. Journal of Medical Systems 44(7): 132. https://doi.org/10.1007/s10916-020-01596-5

Ayati N, Saiyarsarai P, Nikfar S (2020) Short and long term impacts of COVID-19 on the pharmaceutical sector. DARU Journal of Pharmaceutical Sciences 28: 799-805. https://doi.org/10.1007/s40199-020-00358-5

Badreldin HA, Atallah B (2021) Global drug shortages due to COVID-19: Impact on patient care and mitigation strategies. Research in Social and Administrative Pharmacy 17(1): 1946-1949. https://doi. org/10.1016/j.sapharm.2020.05.017

Ballard M, Bancroft E, Nesbit J, Johnson A, Holeman I, Foth J, Rogers D, Yang J, Nardella J, Olsen H, Raghavan M, Panjabi R, Alban R, Malaba S, Christiansen M, Rapp S, Schechter J, Aylward P, Rogers A, Sebisaho J, Ako C, Choudhury N, Westgate C, Mbeya J, Schwarz R, Bonds MH, Adamjee R, Bishop J, Yembrick A, Flood D, McLaughlin M, Palazuelos D (2020) Prioritising the role of community health workers in the COVID-19 response. BMJ Global Health 5: e002550. https://doi.org/10.1136/bmjgh-2020-002550

Boškoski I, Gallo C, Wallace MB, Costamagna G (2020) COVID-19 pandemic and personal protective equipment shortage: protective efficacy comparing masks and scientific methods for respirator reuse. Gastrointestinal Endoscopy 92(3): 519-523. https://doi.org/10.1016/j. gie.2020.04.048

Caetano R, Silva AB, Menezes Guedes ACC, de Paiva CCN, da Rocha Ribeiro G, Santos DL, da Silva RM (2020) Desafios e oportunidades para telessaúde em tempos da pandemia pela COVID-19: uma reflexão sobre os espaços e iniciativas no contexto brasileiro. Cadernos de Saúde Pública 36(5): e00088920. https://doi.org/10.1590/0102-311x00088920

Cavaleri M, Enzmann H, Straus S, Cooke E (2021) The European Medicines Agency`s EU conditional marketing authorizations for COVID-19 vaccines. The Lancet 397(10272): 355-357. https://doi. org/10.1016/S0140-6736(21)00085-4 ment and the uncertain financial market, 2020 and 2021 are no exception to large mergers and acquisitions. Eli Lilly acquired gene therapy company Prevail for $\$ 1$ billion. Cadent Therapeutics entered into a $\$ 770$ million acquisition agreement with Novartis and others (The Pharmaletter 2020a, 2020b).

\section{Conclusion}

In the conditions of the COVID-19 pandemic, timely and adequate changes were made in the Bulgarian pharmaceutical and drug legislation, which aimed at faster coping with the COVID crisis, which affected all aspects of public and social life.Despite these difficulties, the pharmaceutical sector finds effective solutions not only to continue, but also to optimize its activity, adapting itself to the changing reality.

Cohen J, van der Meulen Rodgers Y (2020) Contributing factors to personal protective equipment shortages during the COVID-19 pandemic. Preventive Medicine 141: 106263. https://doi.org/10.1016/j. ypmed.2020.106263

Doraiswamy S, Abraham A, Mamtani R, Cheema S (2020) Use of Telehealth During the COVID-19 Pandemic: Scoping Review. Journal of Medical Internet Research 22(12): e24087. https://doi.org/10.2196/24087

EFPIA [European Federation of Pharmaceutical Industries and Associations] (2020) European Federation of Pharmaceutical Industries and Associations. https://www.efpia.eu/covid-19/member-updates/ [Accessed on June 2021]

FIP [International Pharmaceutical Federation] (2020) International Pharmaceutical Federation. www.fip.org [ Accessed on June 2021]

Galiero R, Pafundi PC, Nevola R, Rinaldi L, Acierno C, Caturano A, Salvatore T, Adinolfi LE, Costagliola C, Sasso FC (2020) The importance of telemedicine during COVID-19 pandemic: a focus on diabetic retinopathy. Hindawi. Journal of Diabetes Research 2020: e9036847. https://doi.org/10.1155/2020/9036847

Golan MS, Jernegan LH, Linkov I (2020) Trends and applications of resilience analytics in supply chain modeling: systematic literature review in the context of the COVID-19 pandemic. Environment Systems and Decisions 40: 222-243. https://doi.org/10.1007/s10669-020-09777-w Google Finances Moderna (2021) Google Finances: Moderna. https:// www.google.com/finance/quote/MRNA:NASDAQ? window=5Y

Google Finances Novavax (2021) Google Finances: Novavax, Inc. https:// www.google.com/finance/quote/NVAX:NASDAQ? window=5Y

Google Finances BioNTech (2021) Google Finances: BioNTech. https:// www.google.com/finance/quote/BNTX:NASDAQ? window=5Y

Haque SN (2021) Telehealth Beyond COVID-19. Psychiatric Services 72(1): 100-103. https://doi.org/10.1176/appi.ps.202000368 [Epub 2020 Aug 19] [PMID: 32811284]

Hussain MT, Aroosa L, Arooj A, Habib KY, Hadal AN, Ibrahim AA, Nida T, Mehmood KT (2020) Multilevel engagements of pharmacists during the COVID-19 Pandemic: The way forward. Frontiers in Public Health 8: e561924. https://doi.org/10.3389/fpubh.2020.561924

Lambert H, Gupte J, Fletcher H, Hammond L, Lowe N, Pelling M, Raina N, Shahid T, Shanks K (2020) COVID-19 as a global challenge: towards 
an inclusive and sustainable future. The Lancet Planetary Health 4(8): e312-e314. https://doi.org/10.1016/S2542-5196(20)30168-6

Lieneck C, Garvey J, Collins C, Graham D, Loving C, Pearson R (2020) Rapid telehealth implement during the COVID-19 Global Pandemic: A rapid review. Healthcare (Basel) 8(4): e517. https://doi. org/10.3390/healthcare8040517

Mann DM, Chen J, Chunara R, Testa PA, Nov O (2020) COVID-19 transforms health care through telemedicine: Evidence from the field. Journal of the American Medical Informatics Association 27(7): 1132-1135. https://doi.org/10.1093/jamia/ocaa072

McCabe C (2020) ESG Viewpoint - COVID-19 and the pharmaceutical industry. BMO Global Asset Management. https://www.bmogam.com/viewpoints/responsible-investment/esg-viewpoint-covid-19-and-the-pharmaceutical-industry/

McKee M, Stuckler D (2020) If the world fails to protect the economy, COVID-19 will damage health not just now but also in the future. Nature Medicine 26: 640-642. https://doi.org/10.1038/s41591-020-0863-y

Merks P, Jakubowska M, Drelich E, Świeczkowski D, Bogusz J, Bilmin K, Sola KF, May A, Majchrowska A, Koziol M, Pawlikowski J, Jaguszewski M, Vaillancourt R (2021) The legal extension of the role of pharmacists in light of the COVID-19 global pandemic. Research in Social and Administrative Pharmacy 17(1): 1807-1812. https://doi. org/10.1016/j.sapharm.2020.05.033

Pharmaceutical Technology (2021) COVID-19 accelerated digital transformation of the pharma industry by five years: Poll. Pharmaceutical Technology. https://www.pharmaceutical-technology.com/news/ covid-19-accelerated-digital-transformation-of-the-pharma-industry-by-five-years-poll/

Pinto GS, Hung M, Okoya F, Uzman N (2021) FIP's response to the COVID-19 pandemic: Global pharmacy rises to the challenge. Research in Social and Administrative Pharmacy 17(1): 1929-1933. https://doi.org/10.1016/j.sapharm.2020.07.004

Pontremoli R, Richard G, Vuddamalay G, Groux N (2020) Fight against COVID-19: market overview and pipeline of ongoing trials. Medical Sciences (Paris) 26(12): 1225-1232. https://doi.org/10.1051/medsci/2020231

PWC (2020) Epidemic Response to COVID-19 in Pharmaceutical and Healthcare Industries Series Issue 2, 7 pp. https://www.pwccn.com/ en/industries/life-sciences-and-healthcare/publications/epidemic-response-covid-19-issue-2.html

Romano S, Galante H, Figueira D, Mendes Z, Rodrigues AT (2021) Time-trend analysis of medicine sales and shortages during COVID-19 outbreak: Data from community pharmacies. Research in Social \& Administrative Pharmacy 17(1): 1876-1881. https://doi. org/10.1016/j.sapharm.2020.05.024

Shuman AG, Fox ER, Unguru Y (2020) COVID-19 and drug shortages: a call to action. Journal of Managed Care \& Specialty Pharmacy 26(8): 945-947. https://doi.org/10.18553/jmcp.2020.26.8.945

Sousa Pinto G, Hung M, Okoya F, Uzman N (2021) FIP's response to the COVID-19 pandemic: Global pharmacy rises to the challenge. Research in Social \& Administrative Pharmacy 17(1): 1929-1933. https://doi.org/10.1016/j.sapharm.2020.07.004

The Irish Times (2021) Pharma sector not immune to the effects of Covid-19. The Irish Times. https://www.irishtimes.com/business/ health-pharma/pharma-sector-not-immune-to-the-effects-of-covid-19-1.4393627

The Pharmaletter (2020a) Lilly to buy gene therapy firm Prevail for \$1 billion. The Pharmaletter. https://www.thepharmaletter.com/article/ lilly-to-buy-gene-therapy-firm-prevail-for-1-billion

The Pharmaletter (2020b) Cadent Therapeutics accepts takeover bid from Novartis. The Pharmaletter. https://www.thepharmaletter.com/ article/cadent-therapeutics-accepts-takeover-bid-from-novartis

Todorov T (2020) How COVID-19 affected the financial reports on stock companies. Capital. https://www.capital.bg/moiat_capital/investments/2020/09/11/4112190_kak_covid-19_se_otrazi_na_finansovite_otcheti_na/ [In Bulgarian]

Visacri MB, Figueiredo IV, de Mendonça Lima T (2021) Role of pharmacist during the COVID-19 pandemic: A scoping review. Research in Social \& Administrative Pharmacy 17(1): 1799-1806. https://doi. org/10.1016/j.sapharm.2020.07.003

West NEJ, Cheong WF, Boone E, Moat NE (2020) Impact of the COVID-19 pandemic: a perspective from industry. European Heart Journal Supplements 22(Suppl_P): P56-P59. https://doi.org/10.1093/ eurheartj/suaa187

WHO [World Health Organization] (2021) WHO, World Health Organization. www.who.int [Accessed June 2021] 